\title{
Synthesis and Characterization of $\boldsymbol{n}$-octyl Chemically Modified Diatomaceous Earth
}

\author{
Olivia Florena Măruţoiu, ${ }^{\mathrm{a}, *, \dagger}$ Ioan Bratu, ${ }^{\mathrm{b}, \dagger}$ Sorin Hodişan, ${ }^{\mathrm{c}}$ and Cristian Tigae ${ }^{\mathrm{d}}$ \\ a "Babes-Bolyai" University Cluj-Napoca, Faculty of Chemistry and Chemical Engineering, \\ 11 Arany Janos Street, Cluj-Napoca, 400028, Romania \\ ${ }^{\mathrm{b}}$ National Institute of $R \& D$ for Isotopic and Molecular Technology, \\ 65-103 Donath Street, Cluj-Napoca, 400293, Romania \\ ${ }^{\mathrm{c}}$ University of Oradea, Faculty of Sciences, 1 University Street, Oradea, 410087, Romania \\ ${ }^{\mathrm{d}}$ University of Craiova, Faculty of Chemistry, 165 Calea Bucuresti Street, Craiova,1100, Romania
}

RECEIVED AUGUST 1, 2012; REVISED OCTOBER 7, 2013; ACCEPTED OCTOBER 17, 2013

\begin{abstract}
A stationary phase for thin layer chromatography has been prepared through binding triethoxyoctylsilane with the purified diatomaceous earth (rich in silica). The phase has been characterized by elemental analysis, measurement of specific area, FTIR spectroscopy, thermal analysis and chromatographic testing. (doi: $10.5562 / \mathrm{cca} 2162$ )

Keywords: TLC, reversed phase TLC, diatomaceous earth, bonded phase synthesis, $n$-octyl-bonded diatomaceous earth
\end{abstract}

\section{INTRODUCTION}

The reversed phase liquid chromatography using open or closed columns is a very popular and frequently used technique in the current times. The $\mathrm{C}_{8}$ and $\mathrm{C}_{18}$ chemically modified stationary phases are the most frequently used for separations. ${ }^{1,2}$ Thin layer chromatography has become a modern and efficient method following the introduction of chemically modified stationary phases and quantitative determination devices. A chemically modified stationary phase consists from a support that has an organic compound bonded to its surface. Various compounds that have hydroxyl groups were used as supports: silica gel, ${ }^{3-8}$ volcanic tuffs, ${ }^{9,10}$ alumina, ${ }^{11}$ diatomaceous earth. ${ }^{12}$

A number of minerals were used in order to obtain stationary phases for thin layer chromatography. Therefore, activated bentonite, ${ }^{13}$ Sinai clay, ${ }^{14}$ China clay, ${ }^{15}$ modified perlite, ${ }^{16}$ volcanic tuff ${ }^{9,10,17}$ and diatomaceous earth ${ }^{12,18-21}$ were successfully used as stationary phases in thin layer chromatography.

Diatomaceous earth, also known as diatomite or kieselgur (name of German origin), is a sedimentary siliceous rock mainly formed from petrified remains of some mono cellular microscopic algae, basically made of $\mathrm{SiO}_{2}$. It is a siliceous rock mainly made of diatom shell remains. Because of its structure and composition, diatomite is used as: chemical adsorbent with recommended use for toxic liquids retention for chemical accidents; water adsorbent, drying agent; oil adsorbent that can be used in the event of accidental oil spills; fertilizing agent (used as anti-agglomerant); hydroponic medium for plant growing; herbicide and fungicide carrier for agriculture; filtering material with applications in the food industry (beverage and/or food processing); filtering material for general use (water filtering in pools); filling material for ceramic, polymeric and paint industry; as a light building material, good sound insulating material; additive in cement industry; material for the thermal insulation for furnaces or other devices that work under high temperature conditions.

All these applications and the chemical composition, especially the high $\mathrm{SiO}_{2}$ content of the diatomaceous earth make it a study subject for producing stationary phases for liquid chromatography, and especially for thin layer chromatography.

The aim of this paper was to prepare and characterize a new chromatographic stationary phase as being cheaper and easily to obtain.

\footnotetext{
$\dagger$ Jointly first authors

* Author to whom correspondence should be addressed. (E-mail: oliviaflorenamarutoiu@yahoo.it)
} 


\section{EXPERIMENTAL}

\section{Chemicals, Reagents and Materials}

Diatomaceous earth from Minis, Arad district (Romania) was employed. Chlorhydric acid, toluene, xylene, methylene chloride, methanol, ethanol, $\mathrm{H}_{3} \mathrm{PO}_{4}$ triethoxyoctylsilane, $\mathrm{AgNO}_{3}, \mathrm{KBr}$, TLC plates silica gel $\mathrm{C}_{8}$ (Merck), food dyes (amaranth, erythrosine, brilliant blue, patent blue $\mathrm{V}$, quinoline yellow, tartrazine, ponceau 4R) (Fluka).

\section{Synthesis of $\boldsymbol{n}$-Octyl Modified Minis Diatomaceous Earth Stationary Phase}

The micronized white Minis diatomaceous earth, with high silica content, has a composition of $80.18 \% \mathrm{SiO}_{2}$, $6.53 \% \mathrm{Al}_{2} \mathrm{O}_{3}, 0.85 \% \mathrm{Fe}_{2} \mathrm{O}_{3}, 1.35 \% \mathrm{CaO}, 0.56 \%$ $\mathrm{MgO}, 0.34 \% \mathrm{Na}_{2} \mathrm{O}, 0.60 \% \mathrm{~K}_{2} \mathrm{O}, 0.33 \% \mathrm{TiO}_{2}$ and the rest until $100 \%$ is made of volatile materials. The diatomaceous earth was purified ${ }^{12}$ with $6 \mathrm{M}$ hydrochloric acid to remove traces of iron that decrease the white degree and interferes with the visualized compounds in thin layer chromatography. After purification, the diatomaceous earth was washed with distilled water until it was chlorine free (reaction with $\mathrm{AgNO}_{3}$ ). The $\mathrm{pH}$ of the purified material was corrected with $5 \% \mathrm{NaOH}$ until $\mathrm{pH}=7$ was reached, and then it was dried in a stove at $100{ }^{\circ} \mathrm{C}$. A quantity of 100 grams of purified and $100{ }^{\circ} \mathrm{C}$ activated Minis diatomaceous earth was inserted into a flask with 3 necks, and then $400 \mathrm{~mL}$ of xylene (dried on a molecular sieve) were added. The reaction was performed in a nitrogen atmosphere. In order to avoid moisture from entering the system, the installation was provided with a small tube containing calcium chloride. When the reaction mass reached $60^{\circ} \mathrm{C}, 20 \mathrm{~g}(23 \mathrm{ml})$ of triethoxyoctylsilane were added through the dropping funnel. After the entire quantity of the organic silicon material was added, the reaction mixture was stirred and heated to $60{ }^{\circ} \mathrm{C}$ for four hours.

After several trials it was established that the optimum mass ratio was 4:1 diatomite: triethoxyoctylsilane. Then the reaction mixture was cooled at room temperature, it was filtered and the resulted material was subjected to gas chromatography analysis that did not highlight the triethoxyoctylsilane presence. The chemically modified diatomite was washed with xylene, methylene chloride and ethyl ether, and then it was vacuum dried. The resulted product is a white powder and it isn't water wetted. The synthesis reaction is presented in Figure 1.

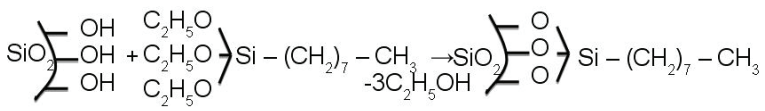

Figure 1. Synthesis reaction of $n$-octyl modified Minis diatomaceous earth.

\section{Specific Surface and Whiteness Degree}

The specific surface area measurements were done using BET method. The whiteness degree was measured with a Zeiss leucometer, using magnesium oxide as standard (whiteness degree $97 \%$ at $\lambda=502 \mathrm{~nm}$ ).

\section{FTIR Spectroscopy and Thermogravimetry}

FT-IR spectra have been recorded with a Jasco-6100 FT-IR spectrometer in the range $4000-400 \mathrm{~cm}^{-1}$ (resolution $4 \mathrm{~cm}^{-1}$ ) using $\mathrm{KBr}$ (Merck Uvasole) pellet technique.

The thermo gravimetric measurements were recorded using a TG-DTA-DTG Mettler Toledo device, in the $25-1100{ }^{\circ} \mathrm{C}$ temperature range, with $5{ }^{\circ} \mathrm{C} / \mathrm{min}$ heating speed in nitrogen atmosphere with $30 \mathrm{ml} / \mathrm{min}$ flow. Aluminum sample cells and approximately $30 \mathrm{mg}$ of samples were used.

\section{Chromatography}

In order to test the chromatographic behavior of the $n$ octyl modified Minis diatomaceous earth, glass chromatographic plates with $10 \times 10 \mathrm{~cm}$ sizes and $0.3 \mathrm{~mm}$ layer thickness were prepared. The glass deposited paste was prepared at room temperature by mixing of $n$-octyl modified diatomaceous earth with a $5 \%$ alcoholic solution of polyvinylpyrrolidone (organic binder). ${ }^{22}$

The $n$-octyl modified diatomaceous earth behavior as a stationary phase was analyzed by separation of seven food dyes. The chromatographic behavior was comparatively studied on $n$-octyl modified diatomaceous earth prepared plates and commercial Merck $\mathrm{C}_{8}$ silica gel plates. Standard solutions $(0.05 \%)$ of the seven dyes were prepared in ethyl alcohol-water (volume ratio $=1: 1) .5 \mu \mathrm{L}$ spot volumes were applied onto the plates with Brand micropipettes. The spotted chromatographic plates were developed by the ascending technique with a methanol-water- $\mathrm{H}_{3} \mathrm{PO}_{4}$ mixture (volume ratio $=50: 50: 1), w\left(\mathrm{H}_{3} \mathrm{PO}_{4}\right)=0,75$ in a normal chromatographic chamber with a $7 \mathrm{~cm}$ distance.

\section{RESULTS AND DISCUSSION}

\section{Coverage Density}

The results of the elemental analysis (carbon, hydrogen), specific surface measurements (BET method) and coverage density are presented in Table 1.

The presence of carbon and hydrogen in the $n$-octyl modified diatomaceous earth and therefore the reduction of the specific surface area of the hydroxylated material from $146.3 \mathrm{~m}^{2} / \mathrm{g}$ to $73.2 \mathrm{~m}^{2} / \mathrm{g}$ indicate the transformation of the diatomite from a hydrophilic material to a hydrophobic one. The calculated coverage 
Table 1. Surface coverage density of $n$-octyl modified Minis diatomaceous earth $\left(\mathrm{C} / \% ; \mathrm{H} / \% ; S_{\mathrm{BET}}\right.$ specific surface; $\alpha$ coverage degree)

\begin{tabular}{ccccc}
\hline Stationary phase & Carbon $/ \%$ & Hydrogen $/ \%$ & $S_{\mathrm{BET}} / \mathrm{m}^{2} \mathrm{~g}^{-1}$ & $\alpha / \mu \mathrm{mol} \mathrm{m}{ }^{-2}$ \\
\hline Minis diatomaceous earth & - & - & 146.3 & - \\
Modified Minis diatomaceous earth & 4.28 & 2.52 & 73.2 & 6.94 \\
\hline
\end{tabular}

degree of $6.94 \mu \mathrm{mol} / \mathrm{m}^{2}$ is in conformity with the literature $^{23,24}$ and offers information about the roles the $-\mathrm{OH}$ groups at the adsorbent surface. The values of whiteness degree for silica gel $\mathrm{RH}$ and diatomaceous earth were found to be $96 \%$ and $89.5 \%$, respectively.

\section{FTIR Spectroscopy}

The FTIR spectra of the diatomaceous earth and of chemically modified one are presented in Figures 2 and 3.

The comparative studies of FTIR spectra for the modified and unmodified Minis diatomaceous earth indicates the surface transformations obtained as a result of the silanization reaction:

- the presence of the modifier $n$-octyl chain is highlighted by the $v(\mathrm{CH}) 2800-3000 \mathrm{~cm}^{-1}$ bands presence, characteristic for the methylene groups $\left(-\mathrm{CH}_{2}-\right)$, bands that are absent in the unmodified diatomite spectrum;

- the silanization reaction determines a reduction of the $\mathrm{OH}$ groups number, which in theory means a decrease of the $v(\mathrm{OH})$ band area in the 3200-3600 $\mathrm{cm}^{-1}$ spectral domain; ${ }^{25}$ in the recorded spectrum using the $\mathrm{KBr}$ pellet technique this quantitative effect is masked by the potassium bromide retained water resulted from the sample preparation process;

- due to the high $\mathrm{SiO}_{2}$ content, in the 800-1300 $\mathrm{cm}^{-1}$ range, characteristic for the $\mathrm{Si}-\mathrm{O}$ bond vibrations, $v(\mathrm{Si}-\mathrm{O})$ and $v(\mathrm{Si}-\mathrm{O}-\mathrm{Si})$ bands shapes changes can be observed for the modified diatomite.

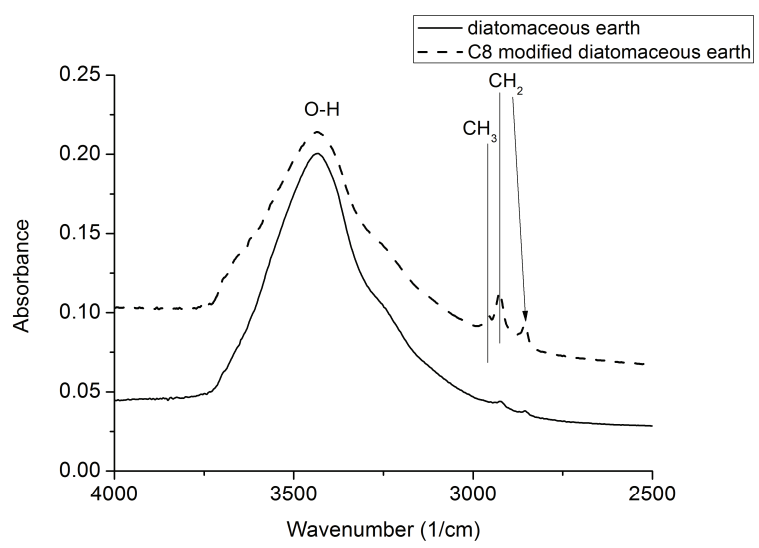

Figure 2. FTIR spectra in the $4000-2500 \mathrm{~cm}^{-1}$ spectral region for unmodified (solid line) and $n$-octyl modified Minis diatomaceous earth (dash line).

\section{Thermo Analytical Study}

By comparing the thermo gravimetric curves for the unmodified and $n$-octyl modified Minis diatomaceous earth (see Figures 4 and 5), a similar thermal behavior can be observed with only one significant difference.

The Minis unmodified diatomaceous earth shows the first mass loss of $4.39 \%$ in the $30-250{ }^{\circ} \mathrm{C}$ temperature interval due the free and chemically bonded water evaporation; in the $250-400{ }^{\circ} \mathrm{C}$ interval a new $0.70 \%$ mass loss can be attributed to the breakdown of some organic substance traces, of some oxides from the diatomaceous earth or of the $\mathrm{FeCl}_{3}$ traces remained from purification. The last $1.97 \%$ mass loss is seen in the 400-900 ${ }^{\circ} \mathrm{C}$ temperature range and can be attributed to the $\mathrm{SiO}_{2}$ breakdown.

The $n$-octyl chemically modified diatomaceous earth shows the first mass loss (quantitatively comparable to the previous sample) of $4.45 \%$ in the $30-230{ }^{\circ} \mathrm{C}$ temperature interval due the free and chemically bonded water evaporation; in the $230-375{ }^{\circ} \mathrm{C}$ temperature domain the $0.81 \%$ mass loss can be attributed to the breakdown of some organic substance traces, or to some oxides from the diatomaceous earth or of the $\mathrm{FeCl}_{3}$ traces remained from purification. For this sample there is an additional $1.49 \%$ mass loss in the $380-510{ }^{\circ} \mathrm{C}$ temperature range compared to the unmodified sample, this event can be attributed to the breakdown of the $\mathrm{C}_{8}$ organic part. The last $2.90 \%$ mass loss is noted in the $510-900{ }^{\circ} \mathrm{C}$ temperature domain and can be attributed to the $\mathrm{SiO}_{2}$ breakdown.

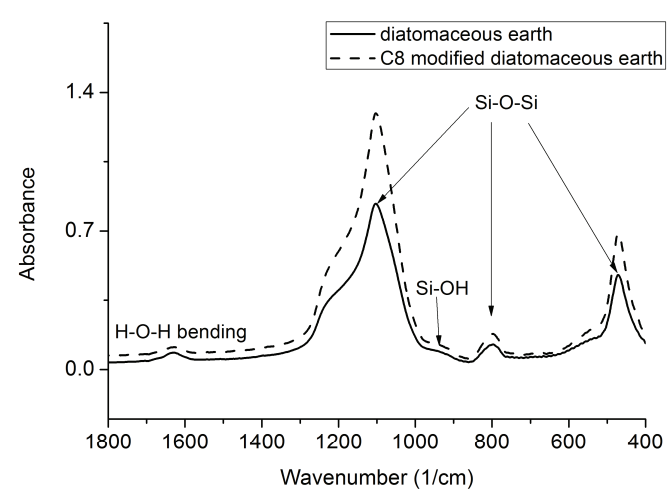

Figure 3. FTIR spectra in the $1800-400 \mathrm{~cm}^{-1}$ spectral region for unmodified (solid line) and $n$-octyl modified Minis diatomaceous earth (dash line). 


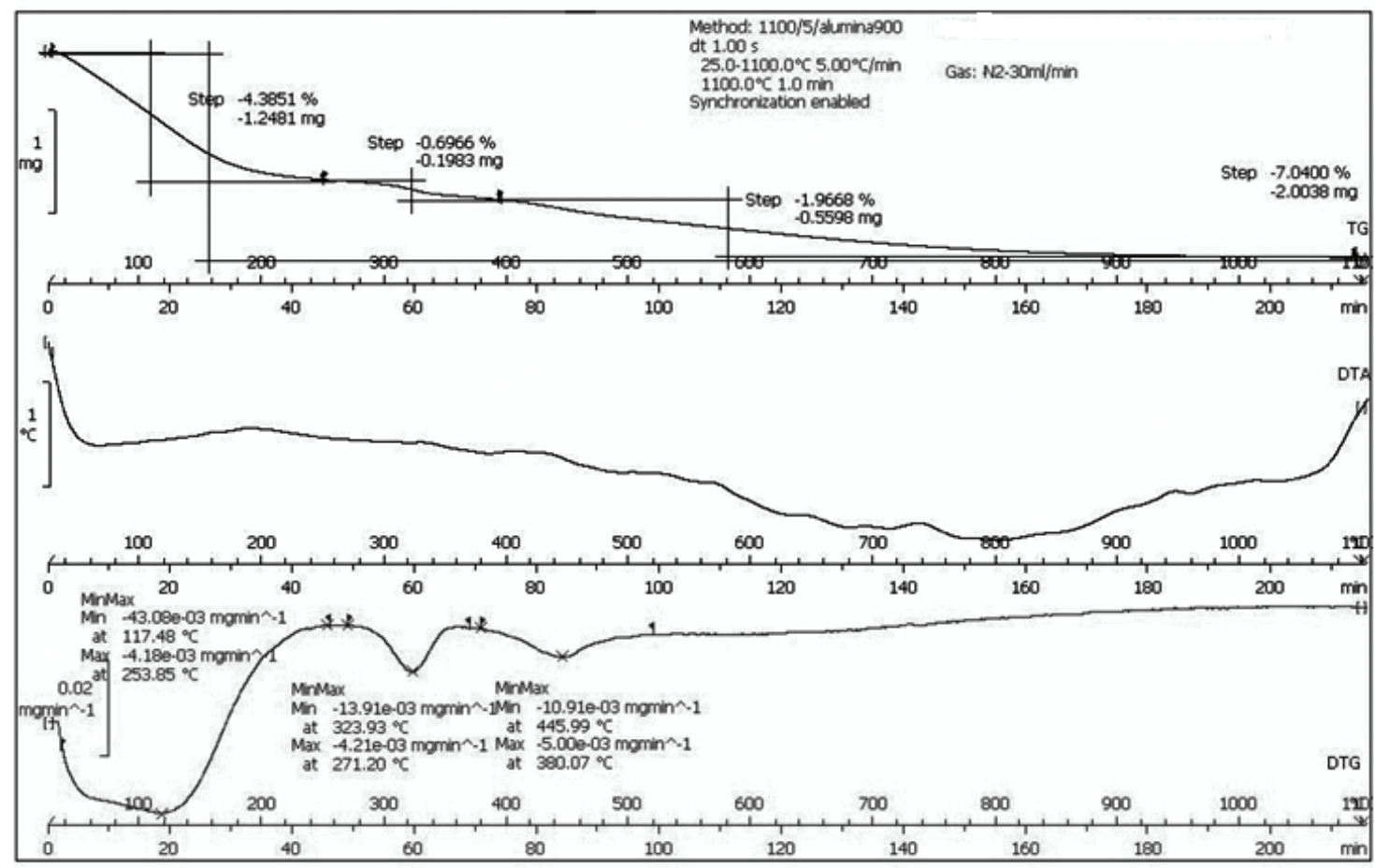

Figure 4. Thermo gravimetric curves for unmodified Minis diatomaceous earth.

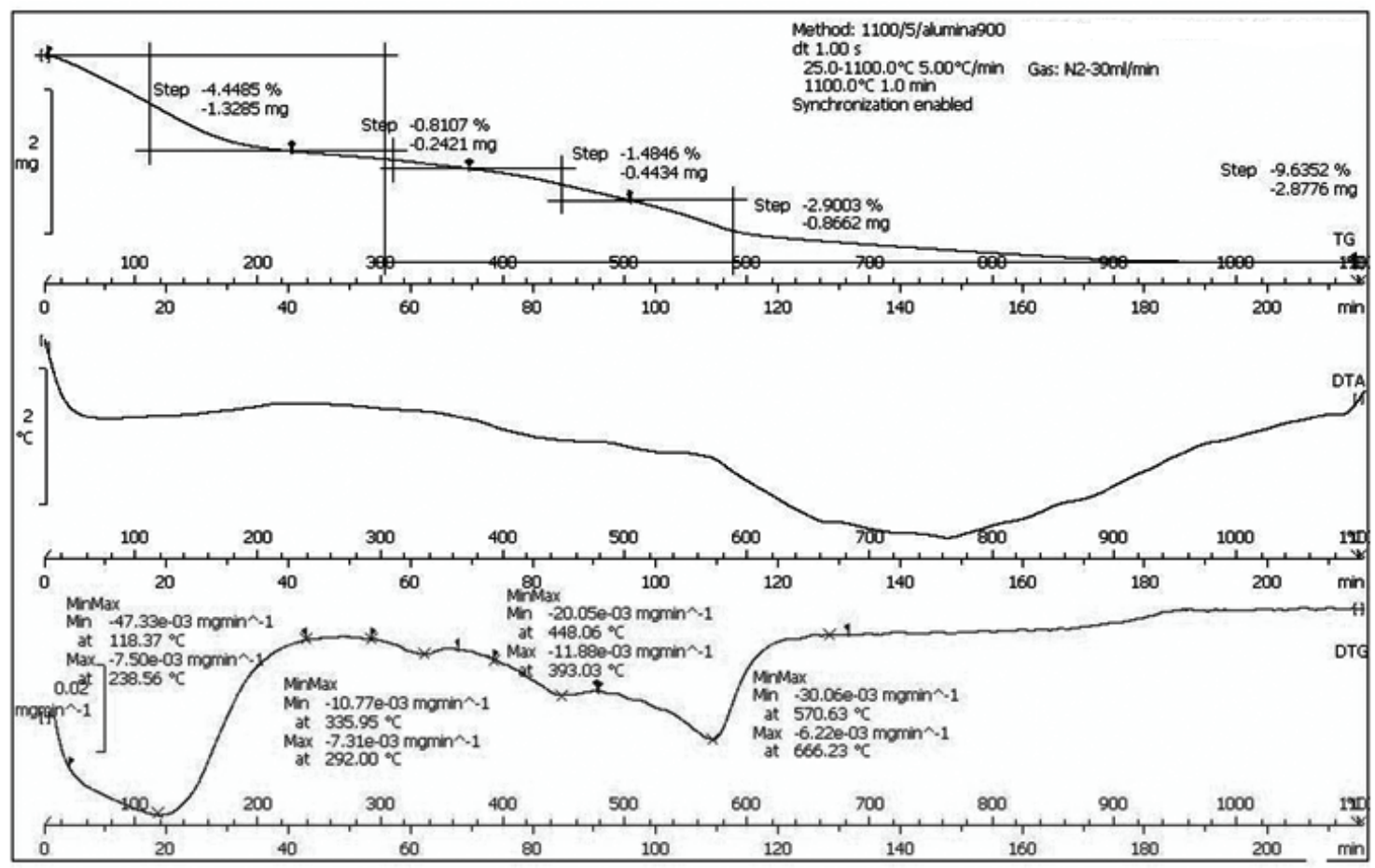

Figure 5. Thermo gravimetric curves for $n$-octyl modified Minis diatomaceous earth.

\section{Chromatographic Behavior}

The $n$-octyl modified Minis diatomaceous earth is a powder with a $94 \%$ white degree (the white degree determination was made with a Zeiss leucometer using
$\mathrm{MgO}$ with a white degree of $97 \%$ for $\lambda=502 \mathrm{~nm}$ as a gage), a value that is similar to silica gel. From the data presented in Table 2 it can be seen that separations were good on both $n$-octyl modified diatomaceous earth plates and on Merck $\mathrm{C}_{8}$ silica gel plates. 
Table 2. The $R_{\mathrm{F}} \times 100$ values of seven food dyes separated on $n$-octyl modified diatomaceous earth plates compared to Merck $\mathrm{C}_{8}$ silica gel plates.

\begin{tabular}{|c|c|c|c|}
\hline Name & Structural formula & $R_{\mathrm{F}} \times 100^{(\mathrm{a})}$ & $R_{\mathrm{F}} \times 100^{(\mathrm{b})}$ \\
\hline Amaranth & & 83 & 88 \\
\hline Erythrosine & & 0 & 0 \\
\hline Brilliant blue & & 40 & 44 \\
\hline Patent blue V & & 22 & 27 \\
\hline Quinoline yellow & & 30 & 32 \\
\hline Tartrazine & & 93 & 96 \\
\hline Ponceau 4R & & 65 & 70 \\
\hline
\end{tabular}

(a) $\mathrm{C}_{8}$ Merck silica gel plates.

(b) $n$-octyl modified diatomaceous earth plates; Mobile phase: methanol-water- $\mathrm{H}_{3} \mathrm{PO}_{4}$ mixture (volume ratio $=50: 50: 1$ ), $w\left(\mathrm{H}_{3} \mathrm{PO}_{4}\right)=0,75$. 
The obtained $R_{\mathrm{F}} \times 100$ values for the studied dyes are better for Merck $\mathrm{C}_{8}$ silica gel plates because of the greater specific surface area of silica gel $\left(500 \mathrm{~m}^{2} \mathrm{~g}^{-1}\right)$ compared to the $n$-octyl modified Minis diatomaceous earth $\left(146.3 \mathrm{~m}^{2} \mathrm{~g}^{-1}\right)$, which leads to a greater coverage degree of the chemical modifier.

\section{CONCLUSIONS}

The results obtained from these studies showed that the chemical modification of the Minis diatomaceous earth surface by the organosilanization reaction with triethoxyoctylsilane transformed its surface from hydrophilic to hydrophobic, that is a new non-polar stationary phase which can be used for separation and identification of various compound classes using the reversed phase thin layer chromatography method.

Acknowledgements. The authors wish to thank for the financial support provided from programs co-financed by The SECTORAL OPERATIONAL PROGRAMME HUMAN RESOURCES DEVELOPMENT, Contract POSDRU 6/1.5/S/3 „Doctoral studies: through science towards society".

\section{REFERENCES}

1. U. D. Neue, HPLC Columns: Theory, Technology, and Practice, Wiley-VCH, New York, 1997.

2. R. E. Majors, $L C G C, 8$ (1990) 760-766.

3. M. J. J. Hetem, J. W. de Haan, H. A. Claessens, C. A. Cramers, A. Deege, and G. Schomburg, J. Chromatogr. 540 (1991) 53-76.

4. M. V. Coman, Compuşi ai siliciului utilizaţi ca faze staţionare în cromatografia de lichide, Teză de doctorat, Cluj-Napoca, (1997).
5. F. Meiouet, G. Felix, H. Taibi, H. Hommel, and A.P. Legrand, Chromatographia 31 (1991) 335-341.

6. R. P. W. Schott, Silica Gel and Bonded Phases. Their production, properties and use in LC, J. Wiley \& Sons, New York, (1993).

7. C. Măruţoiu, R. Constantinescu, and F. Dogar, Rev. Chim. (Bucharest, Rom.) 45 (1994) 600-603.

8. C. Măruţoiu, R. Constantinescu, F. Dogar, and R. Grecu, J. AOAC Int. 82 (1999) 399-401.

9. C. Măruţoiu, R. Constantinescu, F. Dogar, V. Coman, and I. Sarachie, Acta Chromatogr. 8 (1998) 39-47.

10. V. Coman and C. Măruţoiu, J. Planar Chromatogr.--Mod. TLC 7 (1994) 450-452.

11. C. Măruțoiu, M. Filip, C. Tigae, V. Coman, R. Grecu, and Gh. Marcu, J. Planar Chromatogr.--Mod. TLC 16 (2003) 183-185.

12. C. Măruţoiu, C. Tigae, M. I. Moise, A. Popescu, and I. Ilea, J. Planar Chromatogr.--Mod. TLC 16 (2003) 32-35.

13. A. Popov and K. Stepanov, Academie bulgare des Sciences 21 (1968) 673-675.

14. M. B. E. Fayez, G. Gad, I. Nasr, and A. S. Radvan, J. Chem. U. A. R. 10 (1967) 49-54.

15. B. Sheen, J. Chromatogr. 60 (1971) 363-370.

16. R. Karakaş and U. Yuksel, J. Chromatogr. Sci. 36 (1998) 499-504.

17. C. Sârbu, T. Hodişan, C. Liteanu, and C. Măruţoiu, Rev. Chim. (Bucharest, Rom.) 31 (1980) 288-290.

18. S. Ergül, Modification of Diatomaceous Earth and Thin Layer Cromatographic Applications, Ph.D.Thesis, University of Balikesir, Balikesir, Turkey, 2003.

19. S. Ergül, I. Kadan, S. Savaşci, and S. Ergül, J. Chromatogr. Sci. 43 (2005) 394-400.

20. W-T. Tsai, C-W. Lai, and K-J. Hsien, J. Colloid Interface Sci. 297 (2006) 749-754.

21. S. Ergül and Ş. Savaşci, J. Chromatogr. Sci. 46 (2008) 308-315.

22. C. Mărutoiu, M. V. Coman, Placă cromatografică pe bază de silicagel R n-octil; Patent RO, 113278 C (1998).

23. M. W. Ducey Jr., C. J. Orendorff, J. E. Pemberton, and L. C. Sander, Anal. Chem. 74 (2002) 5576-5584.

24. C. J. Orendorff and J. E. Pemberton, Anal. Chem. 77 (2005) 6069-6077.

25. P. C. Ma, J-K. Kim, B. Z. Tang, Carbon 44 (2006) 3232-3238. 